\title{
Costs and Benefits of Home-Based Telecommuting: A Monte Carlo Simulation Model Incorporating Telecommuter, Employer, and Public Sector Perspectives
}

\author{
Kevan R. Shafizadeh, P.E. ${ }^{1}$; Debbie A. Niemeier, P.E. ${ }^{2}$; Patricia L. Mokhtarian ${ }^{3}$; and Ilan Salomon ${ }^{4}$
}

\begin{abstract}
This paper reviews and utilizes the current body of telecommuting related research to study the costs and benefits of home-based telecommuting. Monte Carlo simulation methods were utilized to help account for costs or benefits that remain highly variable or have not been well documented by past research. This study illustrates the conditions under which the business case for telecommuting is supported or weakened. Conditions for the employee (the telecommuter) are generally most favorable when: (1) the employer bears the equipment cost; (2) commute distances are above average; (3) the commute vehicle has below-average fuel economy; (4) travel time is highly valued; and (5) telecommuting is frequent, while conditions for the employer are most favorable when: (1) the telecommuter bears the equipment cost; (2) there is low telecommuter attrition; (3) the employee is highly productive on telecommuting days; (4) the employee's time is highly valued; and (5) telecommuting is frequent. For the employer, telecommuting is also favorable if parking and office space savings are realized. While public sector benefits are conceivable, they remain insignificant in most situations because the impacts on the transportation network are probably not concentrated enough over a specific transportation corridor to realize infrastructure benefits and not quantified or valued enough within a regional air district to realize significant air quality benefits. Further, the public sector loses fuel tax revenue. Altogether, this paper provides insight into the potential public sector impacts of telecommuting, as well as the federal, state, regional, and local public policy implications that arise when telecommuting is considered among other transportation demand management alternatives.
\end{abstract}

DOI: 10.1061/(ASCE)1076-0342(2007)13:1(12)

CE Database subject headings: Telecommunication; Benefit cost ratios; Computer aided simulation; Travel demand; Transportation management.

\section{Introduction}

For more than a decade, transportation planners in federal, state, and local governments have been identifying telecommuting as an important strategy that could help ease congestion on the transportation infrastructure. The 1991 Intermodal Surface Transportation Efficiency Act (ISTEA) allowed state and local governments the flexibility to use federal funding for measures such as telecommuting (U.S. DOT 1997). Substantial progress has been made toward improving our understanding of the advantages and disadvantages of telecommuting (Bernardino and Ben-Akiva 1996; Duxbury et al. 1987; Katz 1987; Yen et al. 1994), as well as our

\footnotetext{
${ }^{1}$ Assistant Professor, Dept. of Civil Engineering, California State Univ.-Sacramento, 6000 J St., Sacramento, CA 95819-6029.

${ }^{2}$ Professor, Dept. of Civil and Environmental Engineering, Univ. of California-Davis, One Shields Ave., Davis, CA 95616 (corresponding author). E-mail: dniemeier@ucdavis.edu

${ }^{3}$ Professor, Dept. of Civil and Environmental Engineering, Univ. of California-Davis, One Shields Ave., Davis, CA 95616.

${ }^{4}$ Professor, Dept. of Geography and School of Public Policy, Hebrew Univ., Jerusalem 91905, Israel.

Note. Discussion open until August 1, 2007. Separate discussions must be submitted for individual papers. To extend the closing date by one month, a written request must be filed with the ASCE Managing Editor. The manuscript for this paper was submitted for review and possible publication on March 30, 2004; approved on September 22, 2005. This paper is part of the Journal of Infrastructure Systems, Vol. 13, No. 1, March 1, 2007. ()ASCE, ISSN 1076-0342/2007/1-12-25/\$25.00.
}

ability to characterize the behavioral aspects associated with adoption and implementation strategies (Bernardino et al. 1993; Gordon and Kelly 1986; Gray et al. 1993; Kugelmass 1995; Nilles 1994; Mahmassani et al. 1993; Mokhtarian and Salomon 1996, 1997). Yet despite technological progress and ample legislative motivation, which make telecommuting more viable than ever, important questions remain regarding the cost effectiveness of telecommuting as both an attractive public transportation policy and a business strategy for companies and individuals (Handy and Mokhtarian 1995). Only relatively recently has an economic evaluation of the impact of telecommuting on the transportation infrastructure been attempted (Yen 2002).

In this study, a cost-effectiveness analysis of home-based telecommuting is conducted using Monte Carlo simulation methods. This study incorporates findings from both macroscale studies, which address some of the transportation and energy benefits of telecommuting in the aggregate, and microscale studies, which provide important information on the employer and employee costs and benefits. All of this information must be combined to provide a complete evaluation because telecommuting must be cost effective to both the employer and employee to be an effective work alternative. Further, the transportation benefits of telecommuting remain dependent on the extent to which it is adopted, and the extent to which it is adopted can be best estimated by objectively evaluating telecommuting and the conditions under which it is most attractive to participants. In particular, this study examines: (1) the conditions under which the personal and business cases for telecommuting are supported or weakened; (2) the 
Table 1. List of Model Inputs

\begin{tabular}{|c|c|}
\hline & Model inputs \\
\hline Growth function & $\begin{array}{l}\text {-Logistic function based on "technological } \\
\text { substitution" theory }\end{array}$ \\
\hline General inputs & $\begin{array}{l}\text {-Annual telecommuting events } \\
\text {-Annual vehicle trips saved } \\
\text {-Annual vehicle miles saved }\end{array}$ \\
\hline Cost inputs & $\begin{array}{l}\text {-Additional home energy expenses }(T) \\
\text { - Telecommuting training }(E) \\
\text {-Equipment and software }(T, E) \\
\text { - Telecommunications services }(E)\end{array}$ \\
\hline Benefit inputs & $\begin{array}{l}\text {-Avoided miscellaneous costs }(T) \\
\text {-Avoided travel costs }(T) \\
\text { - Avoided vehicle maintenance and insurance } \\
\text { costs }(T) \\
\text { - Travel time savings }(T) \\
\text { - Increased employee productivity }(E) \\
\text { - Avoided parking space costs }(E) \\
\text { - Avoided office space costs }(E) \\
\text { - Avoided road construction or maintenance } \\
\text { costs }(P) \\
\text { - Avoided vehicle emissions }(P)\end{array}$ \\
\hline
\end{tabular}

Note: $T=$ telecommuter; $E=$ employer; $P=$ public sector.

potential public sector impacts of telecommuting; and (3) the federal, state, regional, and local public policy considerations that arise when considering telecommuting.

Our model incorporates the best information currently available with respect to these indicators of costs and benefits, and as such the empirical results presented here are of intrinsic interest in their own right. However, given that (1) better information will become available over time, and (2) even with perfect information, costs and benefits would vary with individual circumstances, the more important contribution of this work is the benefit-cost analysis tool itself, which is publicly available from the writers (at 〈http://www.path.berkeley.edu/PATH/Publications/PDF/PRR/ 2000/PRR-2000-20-TELESIMM.xls $\rangle$ ) and can be readily updated or customized with more specific input data.

This paper is organized into five sections. In the next section we present the study methodology by identifying the various cost and benefit inputs, including the assumed growth of telecommuting. We also discuss many of the details associated with the inputs and requisite calculations. The third and fourth sections present the results and related sensitivity analysis, respectively. The final section provides conclusions and policy recommendations.

\section{Study Methodology}

To conduct the cost-effectiveness analysis, we examine two cases: a "fixed case" in which key assumptions are frozen at specified, either typical or conservative, values; and a "simulation case" in which key assumptions are varied according to specified probability distributions. We calculate 10 -year benefit-cost ratios for comparisons. We assume an S-shaped growth function to estimate telecommuting growth over time, along with three categories of explanatory factors (shown in Table 1): general inputs, cost inputs, and benefit inputs. For general inputs we translate the predicted growth in number of telecommuters to number of annual telecommuting events, number of annual trips saved, and number of vehicle miles saved. Cost inputs include home energy, equipment, software, etc., and benefit inputs range from avoided costs associated with travel, parking, and office space savings, to increases in productivity. In this paper, most of the inputs are summarized in tables, including the values that were used, the literature on which the value was based, the justification for the input in the calculation of costs and benefits, as well as an annotated discussion of some of the challenges surrounding each assumption. Aside from the tables, the discussion focuses on transportation-related issues and the benefits to the public sector. A more detailed discussion of all inputs can be found in Shafizadeh et al. (1998, 2000a,b).

Whenever possible, we draw empirical data from both public, macroscale studies, and a handful of small-scale pilot and demonstration projects. The large, macroscale studies have provided estimates of the potential direct impacts of telecommuting on transportation (e.g., vehicle-miles saved, avoided air pollution, avoided fatalities, time savings, and gasoline savings) (U.S. DOT 1993), and indirect impacts, such as energy use and emissions at an aggregate level. The small-scale pilot and demonstration projects [e.g., Southern California Association of Governments (SCAG) 1988; County of San Diego Department of Public Works (CSD-DPW) 1990; JALA Associates 1990; JALA International 1993) provide information regarding typical disaggregate telecommuter and employer costs and benefits, such as additional training costs, communication costs, equipment costs, home energy costs, and miscellaneous telecommuter benefits. Nonetheless, many instances remain, such as the case of infrastructure needs, where certain fundamental relationships have not yet been established in the literature, and some assumptions were required.

\section{Modeling Growth of Telecommuting}

To obtain a telecommuting growth function, we follow work by Blackman in 1974 (Blackman 1974), and later applied by Handy and Mokhtarian in 1996 (Handy and Mokhtarian 1996). The telecommuting growth function can be approximated by assuming the adoption of telecommuting is characterized by low initial growth rates, high rates of growth near the midway point, and low growth rates again near the maximum adoption (or penetration) level, which was defined by Handy and Mokhtarian as the "percentage of telecommuters who telecommute, without regard to frequency" (Handy and Mokhtarian 1996, p. 166). Blackman's general substitution model for technological innovation is given by

$$
\ln \left(\frac{f}{F-f}\right)=c_{1}+c_{2}\left(t-t_{0}\right)
$$

where $f=$ market share captured at time $t ; F=$ upper limit of the market share which the innovation can capture in the long run; $t_{0}=$ year when the innovation first captures a portion of the market; and $c_{1}, c_{2}=$ constants.

In our case, telecommuting is the innovation substituting for traditional commuting to work; $f$ represents the adoption level of telecommuting in year $t$ (as a share of the workforce); and $F$ represents the maximum level of telecommuting adoption achievable by the workforce. The unknown constants $c_{1}$ and $c_{2}$ are parameters that are used to calibrate the model using historical data. To estimate $c_{1}$ and $c_{2}$ we use Blackman's suggestion to fit a regression line to the historical market share data $f$, transformed to the left-hand side of Eq. (1). Calibrating the model requires not only the observed market share data $(f)$, but also that we assume values for the maximum level of telecommuting adoption ex- 
Table 2. Data on Estimated Levels of Telecommuting in United States

\begin{tabular}{cccc}
\hline Year & Telecommuters $^{\mathrm{a}}$ & Workforce $^{\mathrm{b}}$ & $\begin{array}{c}\text { Adoption }^{\mathrm{c}} \\
(\%)\end{array}$ \\
\hline 1988 & 2.5 & 121.7 & 2.05 \\
1989 & 3.5 & 123.9 & 2.82 \\
1990 & 3.5 & 125.8 & 2.78 \\
1991 & 6.0 & 126.3 & 4.75 \\
1992 & 7.0 & 128.1 & 5.46 \\
1993 & 8.5 & 129.2 & 6.58 \\
1994 & 9.1 & 131.1 & 6.94 \\
1995 & 8.5 & 132.3 & 6.42 \\
1996 & 11.1 & 133.9 & 8.29 \\
\hline
\end{tabular}

${ }^{\mathrm{a}}$ Telecommuters in millions. Source: FIND/SVP, Inc. and Link Resources, Inc., as found in, e.g., Gordon (1997).

${ }^{\mathrm{b}}$ Workforce in millions. Source: 1997 U.S. Census Statistical Abstracts.

${ }^{\mathrm{c}}$ Adoption was calculated as telecommuters divided by workforce.

hibited by the workforce $(F)$ and for the year in which telecommuting first captured a portion of the market $\left(t_{0}\right)$.

If we assume that telecommuting first captured a portion of the market in $1980\left(t_{0}=1980\right)$ and that the maximum market share of telecommuting is $20 \%(F=0.20)$, we can fit a line to the historical data shown in Table 2 , and the unknown constants $\left(c_{1}\right.$ and $c_{2}$ ) can be obtained directly from the plot, shown in Fig. 1. The telecommuting market share $f$ is taken to represent the adoption of telecommuting in the workforce, and is calculated by dividing the estimated number of telecommuters in the United States (shown in column 2 of Table 2) by estimated number of individuals in the United States workforce (shown in column 3).

Once the model has been calibrated using available data, we can solve for the market share, $f$, in Eq. (1), which leads to Eq. (2)

$$
f=\frac{F \cdot e^{\left(c_{1}+c_{2} t^{\prime}\right)}}{1+e^{\left(c_{1}+c_{2} t^{\prime}\right)}}
$$

where $t^{\prime}=t-t_{0}$, i.e., the number of years since initial adoption. It is the constrained logistic function given by Eq. (2) that exhibits the "S-shaped" curve typical of rates of technological substitution (Fig. 2). The assumptions on $F$ and $t_{0}$ can obviously be varied. We suggest that $F=0.20$ is likely to be an upper bound, based on more recent data that indicate the adoption of telecommuting in the United States may be flattening out (Mokhtarian et al. 2005).

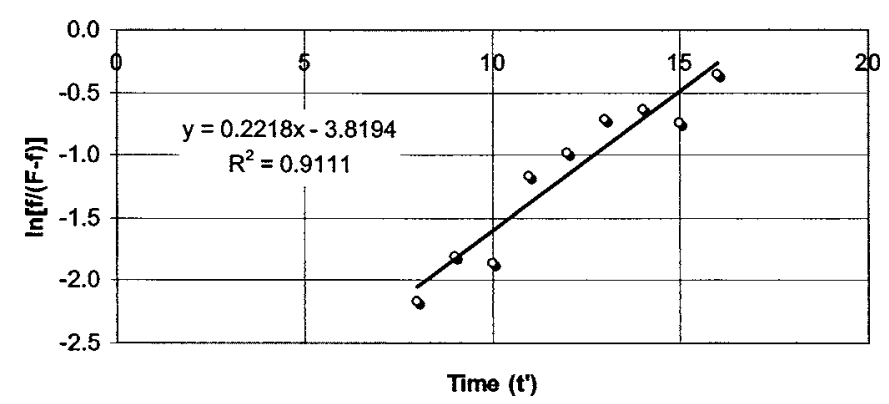

Fig. 1. Telecommuting growth function calibration based on historical data

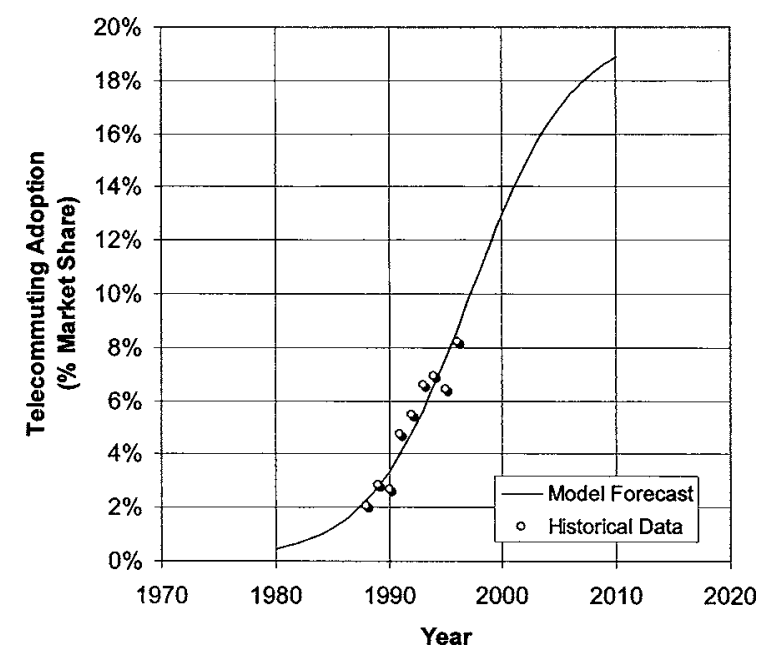

Fig. 2. Forecasted telecommuting growth function

\section{General Inputs, Assumptions, and Calculations}

Along with telecommuting growth, two sets of general assumptions are needed for the benefit-cost analysis calculations. The first set of assumptions relates to vehicle trip characteristics, such as average distance, time, speed, and average fuel economy, and are shown in Table 3. For the purposes of this study, we assume that all transportation-related benefits stem from forgone trips made in single-occupant, light-duty vehicles. The second set of assumptions relates to how telecommuters are converted into annual telecommute events and how annual telecommute events are converted into vehicle trips saved. For these calculations, baseline attrition rates and telecommuting frequencies are established and briefly discussed in Table 4 .

\section{Cost Inputs, Assumptions, and Calculations}

With respect to costs, for this study we assume that costs to the telecommuter are based primarily on additional home energy usage. Home energy costs were estimated to be $\$ 2.40 /$ telecommuting event, based on energy costs of $\$ 132 /$ year/ telecommuter (SCAG 1988) which were divided by 57 telecommute events/year to obtain an average energy cost per telecommute event. For the employer, we include telecommunications installation and service costs as well as additional training costs, as shown in Table 5.

Telecommuting equipment purchase costs (as distinct from the service and maintenance costs shown in Table 5) were explored as being borne by both the telecommuter and the employer. That is, we tested two "all-or-nothing" situations, in which either the telecommuter or the employer pays all of the equipment purchase costs. Although past research indicates that employees are often required to pay for telecommuting equipment without reimbursement (SCAG 1988; County of San Diego DPW 1990), it is also possible for the equipment purchase costs to be the responsibility of the employer. When the employer bears the burden, it is clear that the company would retain ownership of the equipment, and that it could be redistributed to a replacement telecommuter when one employee stops telecommuting.

When the telecommuter bears the equipment burden, however, it is assumed that each new telecommuter will purchase new equipment to telecommute. Clearly, this assumption is conservative, as many telecommuters may already own personal comput- 
Table 3. Trip- and Vehicle-Related Inputs

\begin{tabular}{|c|c|c|c|}
\hline Parameter & $\begin{array}{l}\text { Fixed case } \\
\text { value }\end{array}$ & Reference(s) & Discussion \\
\hline $\begin{array}{l}\text { Average one-way } \\
\text { commute distance }\end{array}$ & $11.6 \mathrm{mi}$ & NPTS (1995) & $\begin{array}{l}\text { - Needed to compute telecommuter avoided travel costs. } \\
\text { - Commute characteristics of telecommuters remain unknown. Mean length } \\
\text { is conservatively assumed to be equal to national average of traditional } \\
\text { (nontelecommuter) commutes based on Mokhtarian et al. (1995). } \\
\text { - Assumed that avoided vehicular travel would have occurred in a light-duty } \\
\text { automobile. } \\
\text { - Commute distance was treated as a Monte Carlo variable in simulations } \\
\text { and allowed to vary, assuming a normal distribution with mean of } 11.6 \text { and } \\
\text { standard deviation of } 4.0 \text { mi. }\end{array}$ \\
\hline Average commute speed & $33.6 \mathrm{mi} / \mathrm{h}$ & NPTS (1995) & - Multiplied by commute distance to obtain travel time savings. \\
\hline $\begin{array}{l}\text { Average one-way } \\
\text { commute time }\end{array}$ & $20.7 \mathrm{~min}$ & NPTS (1995) & $\begin{array}{l}\text { - Needed to compute telecommuter avoided travel time costs. } \\
\text { - Calculated from distance and speed; also corresponds to value in NPTS. }\end{array}$ \\
\hline Average fuel economy & $24.4 \mathrm{mi} / \mathrm{gal}$ & NHTSA (1997) & $\begin{array}{l}\text { - Divided into commute distance saved to obtain fuel savings due to } \\
\text { telecommuting. }\end{array}$ \\
\hline Average fuel "pump" price & $\$ 1.29 / \mathrm{gal}$ & API (1998) & $\begin{array}{l}\text { - Multiplied by fuel savings to obtain avoided fuel costs. } \\
\text { - All grades of fuel, adjusted for inflation. } \\
\text { - Fuel consumption data specifically for telecommuters is not available. }\end{array}$ \\
\hline Average fuel tax & $\$ 0.43 / \mathrm{gal}$ & API (1998) & $\begin{array}{l}\text { - Needed to compute public sector cost of telecommuting. } \\
\text { - For simplicity, no road user fees such as tolls were included in this study. }\end{array}$ \\
\hline
\end{tabular}

ers at their homes and may opt to use their existing equipment instead of purchasing new equipment to telecommute. Furthermore, because it is assumed that each new telecommuter would purchase new equipment, we can see that under this approach equipment costs can become a large component of the overall cost of the project when attrition is high.

In either "all-or-nothing" situation, we assume that equipment is required for each telecommuter and that the net sum of costs for all telecommuters is obtained by multiplying the unit cost of the equipment by the total number of telecommuters. In either situation, the purchase price of a new desktop computing system with software for each telecommuter was assumed to be $\$ 1,800$, based on retail computer equipment prices in the United States and previous research (e.g., JALA International 1993). We also amortize the equipment costs over the life of the computer equipment, which is assumed to be 5 years for computer equipment according to the current federal tax code (Frankel 1996), and we assume that equipment is continuously replaced after reaching its projected life.

\section{Benefit Inputs, Assumptions, and Calculations}

Notable benefits include avoided travel costs and miscellaneous savings by the telecommuter, as highlighted in Table 6 . For the employer, productivity benefits as well as avoided office and parking space costs are possible, as highlighted in Table 7. One of the most attractive aspects of telecommuting is its potential as a travel demand strategy, and air quality benefits and avoided infrastructure construction costs for the public sector are also explored.

It is important to acknowledge that travel time benefits are more complicated than we have indicated here. For example, it is certainly possible that travel time benefits are actually spent as both leisure time and as additional work time. It is also possible that the telecommuter absorbs a smaller portion of the travel time benefit, while a greater portion is given to the employer. Further, it can be argued that even when the saved time is devoted to work, the employee obtains a psychological benefit from getting more work done and that there is some unobserved value in that feeling of productivity. In any event, all benefits to the employer from increased work are considered increases in employee productivity and discussed below.

\section{Avoided Road Construction Costs}

In general, public sector benefits resulting from telecommuting are debatable. In 1994, a Department of Energy report suggested that benefits from telecommuting could result if construction of additional freeway or arterial lanes could be avoided (U.S. DOE 1994). Hypothetically, it is conceivable that public sector benefits could be realized if commute trips were highly concentrated in an isolated corridor at the same time (e.g., during the morning and afternoon peak commute periods). For example, if a large office park located close to an urban freeway served a sizeable telecommuting workforce, telecommuting could impact the travel demand on the freeway segment and arterials and ramps during the peak commute periods.

To explore the impacts of telecommuting on a specific roadway corridor, we have used the analysis methodology recommended by the 1997 Highway Capacity Manual (HCM) to show that for telecommuting to maintain a level of service equal to that of adding a freeway lane, it would need to be responsible for removing more than 1,530 vehicles from the peak hour on a single freeway section (Shafizadeh et al. 2000b). If $76 \%$ of telecommute events result in drive-alone trips as assumed in Table 4, we would need to ensure that more than 2,013 employees who would have used that freeway section during the peak hour telecommute each day (requiring 8,388 employees to telecommute 1.2 days/week on average) to achieve a 1,530-vehicle reduction in demand. Depending on the length of the peak, this reduction may need to be sustained for more than $1 \mathrm{~h}$. Simply put, it seems unlikely that these concentrated reductions in demand can be consistently achieved at a localized level. If this 1,530 vehicle/h reduction is not achieved, then any reduction in demand would simply result in an improved level of service, and the forgone cost of adding a lane would not be justified. While there may be some 
Table 4. Telecommuting Conversion Factors and Inputs

\begin{tabular}{|c|c|c|c|}
\hline Parameter & $\begin{array}{l}\text { Fixed case } \\
\text { value }\end{array}$ & Reference(s) & Discussion \\
\hline $\begin{array}{l}\text { Average telecommuting } \\
\text { frequency }\end{array}$ & $\begin{array}{l}1.2 \text { days/week } \\
(24 \%)\end{array}$ & $\begin{array}{l}\text { Handy and } \\
\text { Mokhtarian } \\
\quad(1995)\end{array}$ & $\begin{array}{l}\text { - One of the most critical parameters in the benefit-cost analysis. } \\
\text { - Needed to convert the number of telecommuters into annual } \\
\text { telecommute "events"- - before annual telecommute events can be } \\
\text { converted into vehicle trips saved. } \\
\text { - Treated as a Monte Carlo variable in simulations and was } \\
\text { assumed to be normally distributed with mean of } 1.2 \text { and a } \\
\text { standard deviation of } 0.3 \text { days/week. }\end{array}$ \\
\hline $\begin{array}{l}\text { Traditional workdays } \\
\text { per year }\end{array}$ & 236 & Assumed & $\begin{array}{l}\text { - Needed to compute the number of telecommute days per year } \\
\text { (i.e., } 24 \% \text { of } 236 \text {, or } 57 \text { workdays per year). } \\
\text { - Computed by assuming } 104 \text { weekend days, ten federal holidays, } \\
\text { and } 15 \text { days of vacation in the } 365 \text {-day year. } \\
\text { - Assumed that one and only one commute or telecommute event } \\
\text { occurs on each workday. }\end{array}$ \\
\hline $\begin{array}{l}\text { Average annual } \\
\text { telecommuting } \\
\text { attrition rate }\end{array}$ & $35 \% /$ year & $\begin{array}{c}\text { Assumed, } \\
\text { based on } \\
\text { Varma et al. } \\
\text { (1998) }\end{array}$ & $\begin{array}{l}\text { - Needed to compute the number of telecommuters. } \\
\text { - Conservative assumption, based on some studies, which have } \\
\text { reported more than } 50 \% \text { attrition within nine months (Varma et al., } \\
\text { 1998). } \\
\text { - Assumed that telecommuters quit and are replaced each year } \\
\text { ("replacement telecommuters"), separate from the addition of new } \\
\text { telecommuters attributed to the growth in telecommuting. } \\
\text { - Treated as a Monte Carlo variable in simulations and was } \\
\text { assumed to be uniformly distributed between } 20 \text { and } 50 \% \text { year. }\end{array}$ \\
\hline $\begin{array}{l}\text { Percent of telecommuting } \\
\text { events that eliminate } \\
\text { drive-alone auto trips }\end{array}$ & $76 \%$ & $\begin{array}{l}\text { Mokhtarian } \\
\quad(1998)\end{array}$ & $\begin{array}{l}\text { - Telecommuters who carpool, bicycle, walk, or use transit do not } \\
\text { eliminate drive-alone vehicle trips. } \\
\text { - Approximately 6-14\% of telecommute events are only for partial } \\
\text { days and are still accompanied by a traditional commute } \\
\text { (Mokhtarian 1998). }\end{array}$ \\
\hline $\begin{array}{l}\text { Generated local } \\
\text { non-commute } \\
\text { trip distance }\end{array}$ & $2.0 \mathrm{mi}$ & $\begin{array}{l}\text { Mokhtarian } \\
\text { (1998) }\end{array}$ & $\begin{array}{l}\text { - Assumes that some local travel occurs even on telecommute } \\
\text { days-to run errands, for example. } \\
\text { - Value conservatively represents the largest average value for } \\
\text { generated noncommute travel seen in the literature reviewed for } \\
\text { this study (Mokhtarian 1998). }\end{array}$ \\
\hline
\end{tabular}

Table 5. Employer Cost Inputs, Assumptions, and Calculations

\begin{tabular}{|c|c|c|c|}
\hline Parameter & $\begin{array}{l}\text { Fixed case } \\
\text { value }\end{array}$ & Reference(s) & Discussion \\
\hline $\begin{array}{l}\text { Equipment service and } \\
\text { maintenance expenses }\end{array}$ & $\$ 250 /$ telecommuter/year & JALA (1990) & $\begin{array}{l}\text { - Assumed to be borne by the employer. } \\
\text { - Assumed to involve both technical support and/or related services } \\
\text { to facilitate telecommuting. }\end{array}$ \\
\hline Telecom installation costs & $\$ 100 /$ telecommuter & $\begin{array}{l}\text { SCAG }(1988) ; \\
\text { CSD-DPW (1990); } \\
\text { JALA }(1993)\end{array}$ & $\begin{array}{l}\text { - Assumed to be the installation of an additional phone line. } \\
\text { - Assumed one-time cost for all new and replacement (due to } \\
\text { attrition) telecommuters. } \\
\text { - Values were based on a review of the microscale literature, which } \\
\text { indicates startup costs between } \$ 85 \text { and } \$ 91 \text {. }\end{array}$ \\
\hline Telecom service costs & $\$ 360 /$ telecommuter/year & SCAG (1988) & $\begin{array}{l}\text { - Assumed ongoing cost for all telecommuters. } \\
\text { - Assumed to be } \$ 30 / \text { month based on SCAG (1988). Total startup } \\
\text { costs (installation and service) of } \$ 400-500 \text { were noted by Kunkle } \\
\text { (1992), and } \$ 360 \text { Canadian }(\sim \$ 240 \text { United States) was noted by } \\
\text { Finlay (1991). }\end{array}$ \\
\hline Telecommuting training & $\$ 300 /$ telecommuter & JALA (1990) & $\begin{array}{l}\text { - Assumed cost per supervisor-telecommuter pair (i.e., additional } \\
\text { training costs are incurred whenever a new employee starts } \\
\text { telecommuting). } \\
\text { - Assumed (conservatively) a supervisor manages only one } \\
\text { telecommuter. }\end{array}$ \\
\hline
\end{tabular}


Table 6. Telecommuter Benefit Inputs, Assumptions, and Calculations

\begin{tabular}{|c|c|c|c|}
\hline Parameter & $\begin{array}{l}\text { Fixed case } \\
\text { value }\end{array}$ & Reference(s) & Discussion \\
\hline $\begin{array}{l}\text { Miscellaneous benefits } \\
\text { (avoided costs) }\end{array}$ & $\begin{array}{l}\$ 2.15 / \text { telecommuting } \\
\text { event }\end{array}$ & SCAG (1988) & $\begin{array}{l}\text { - Attributed to, for example, eating at home instead of dining } \\
\text { out for lunch, or wearing casual clothes instead of "business" } \\
\text { attire that may require frequent dry cleaning, as noted in many } \\
\text { microscale studies. }\end{array}$ \\
\hline \multirow[t]{3}{*}{$\begin{array}{l}\text { Avoided vehicle insurance } \\
\text { and maintenance costs }\end{array}$} & \multirow[t]{3}{*}{$\$ 0.05 / \mathrm{mi}$} & \multirow[t]{3}{*}{$\begin{array}{l}\text { Reed et al. (1995); } \\
\text { AAA (1998); and } \\
\text { based on FHWA (1992) }\end{array}$} & $\begin{array}{l}\text { - Fuel costs represent only a fraction of the total cost of owning } \\
\text { and operating an automobile, as the average cost for automobile } \\
\text { ownership was estimated to be approximately } 39.5 \text { cents/vehicle/ } \\
\text { mi, of which insurance and maintenance costs were } \\
\text { approximately } 26 \text { and } 15 \% \text {, respectively ( } 16.2 \text { cents/mi total), } \\
\text { while fuel costs (with taxes) were only } 15 \% \text { (FHWA 1992). }\end{array}$ \\
\hline & & & $\begin{array}{l}\text { - Five cents per vehicle mile was documented by Reed et al. } \\
\text { (1995) and a similar value was noted by the American } \\
\text { Automobile Association (1998). To be conservative, we adopt } \\
\text { this lower number. }\end{array}$ \\
\hline & & & $\begin{array}{l}\text { - Assumed to be a function of travel distance and calculated } \\
\text { similarly to avoided travel costs. }\end{array}$ \\
\hline \multirow[t]{4}{*}{$\begin{array}{l}\text { Value of avoided } \\
\text { travel time }\end{array}$} & \multirow[t]{4}{*}{$\$ 6.00 / \mathrm{h}$} & \multirow[t]{4}{*}{$\begin{array}{l}\text { Krusi (1997); and based } \\
\text { on Reed et al. (1995); } \\
\text { Dowling Associates (1999); } \\
\text { Schrank and Lomax (1999) }\end{array}$} & $\begin{array}{l}\text { - Travel time savings due to telecommuting can be considered } \\
\text { either saved "work time" or saved "leisure time." If the saved } \\
\text { time is for work purposes, then it can be considered a benefit to } \\
\text { the employer (as discussed in Table 7) and valued as a function } \\
\text { of an individual's hourly wage rate. If the saved time is for } \\
\text { leisure purposes, however, then the savings would be } \\
\text { considered a benefit to the telecommuter and would be valued } \\
\text { at a lower rate. }\end{array}$ \\
\hline & & & $\begin{array}{l}\text { - In transportation studies, travel time is valued at one-third to } \\
\text { one-half of the average hourly wage rate, an amount which has } \\
\text { been shown to be as low as } \$ 6.30 / \mathrm{h} \text { [Reed et al. 1995, also see } \\
\text { Dowling Associates (1999)] and as high as } \$ 11.70 \text { when } \\
\text { estimating the cost of congestion (Schrank and Lomax 1999). }\end{array}$ \\
\hline & & & $\begin{array}{l}\text { - In 1997, the U.S. DOT released a memorandum on the } \\
\text { valuation of travel time for the use of all federal agencies } \\
\text { conducting economic analyses, in which a minimum range of } \\
\$ 6.00-\$ 10.20 \text { was given for personal, local travel (Krusi 1997). }\end{array}$ \\
\hline & & & $\begin{array}{l}\text { - Treated as a Monte Carlo variable in simulations and allowed } \\
\text { to vary between } \$ 6.00 \text { and } \$ 10.20 / \mathrm{h} \text {, assuming a uniform } \\
\text { distribution. }\end{array}$ \\
\hline
\end{tabular}

quantifiable public sector benefit obtained from an improvement in the level of service due to a general reduction in travel time, these benefits are not explored in this study.

So while telecommuting remains a viable strategy to address overall travel demand, it is difficult to justify the assertion that it can impact infrastructure construction costs, even along a localized corridor. Telecommuting can be expected to contribute to an overall reduction in travel demand, but it is more likely to produce a regional, systemwide improvement in travel rather than preventing the construction of additional lanes. The physical effects of telecommuting would probably be dispersed throughout the transportation system, not all of which operates at capacity.

Telecommuting does not work effectively as a transportation systems management tool because it cannot be controlled to affect specific saturated corridors during the peak periods. Others have assumed that telecommuters are evenly distributed throughout the transportation network but that the entire transportation network is saturated during the peak period (Yen 2002).

\section{Avoided Vehicle Emissions}

Quantifying air quality impacts depends on vehicle miles of travel (VMT), engine starting conditions (i.e., cold or hot starts), average speed, vehicle type (including emissions equipment), ambient air temperature, and driver behavior (California Air Resources
Board 1996). We use a conservative approximation by calculating: (1) start emissions based on start emission factors along with (2) running exhaust emissions by using VMT estimates, assuming a constant running speed $(35 \mathrm{mi} / \mathrm{h}$, based on a value of $33.6 \mathrm{mi} / \mathrm{h}$ from the 1995 NPTS) and using emission factors from California's EMFAC7G inventory emission model (CARB 1996).

We assumed that the forgone commute would have been made in a light-duty, gasoline-powered automobile with a catalytic converter. Because a growing portion of the vehicle fleet in this country comprises light-duty trucks or sport-utility vehicles with lower fuel economies than light-duty automobiles, these assumptions will likely underestimate the air quality benefits of telecommuting (NPTS 1995). In other words, the current vehicle fleet almost certainly consumes more gasoline per mile and produces more emissions per gallon of gasoline than assumed here. We assumed a hot soak time of 120 min to obtain the start emission rates.

Once pollutant loads were calculated, they were monetized using values shown in Table 8. As discussed in detail by Wang and Santini (1995), the cost of emissions can be estimated using two different approaches, a damage value method and a cost control method, resulting in a range of possible monetizing values. For the fixed case, the most conservative estimates (i.e., the lowest) were used in the benefit-cost analysis calculations. For the 
Table 7. Employer Benefit Inputs, Assumptions, and Calculations

\begin{tabular}{|c|c|c|}
\hline Parameter & $\begin{array}{l}\text { Fixed case } \\
\quad \text { value }\end{array}$ & Reference(s) \\
\hline $\begin{array}{l}\text { Net change in productivity } \\
\text { due to telecommuting }\end{array}$ & $7.5 \%$ & $\begin{array}{l}\text { Assumed, based on } \\
\text { values indicated } \\
\text { in JALA (1990); } \\
\text { JALA (1993); } \\
\text { CSD-DPW (1990) }\end{array}$ \\
\hline
\end{tabular}

Discussion

Telecommuter

annual salary

$\$ 35,000 /$ year

Assumed, based on values from NPTS (1995) and U.S. Census (1998)

Washington Council

of Governments (1991)

Avoided parking

space expenses

$\$ 3.50$

Avoided office space

$100 \mathrm{ft}^{2}$

Assumed

Office space

$50 \%$

Assumed

utilization factor

Value of avoided

office space
$\$ 0 / \mathrm{ft}^{2} /$ year $\quad$ Assumed, based on Society of Industrial and Office Realtors

(1998)
- Employee productivity due to telecommuting is not well quantified in the literature, but high levels of increased productivity have been reported by JALA Associates (1990); JALA International (1993); and the County of San Diego, Department of Public Works (1990).

- Increases in productivity due to telecommuting are considered to be an amalgamation of many factors, including (but not limited to): increased quality or quantity of work, increased time spent working, decreased sick leave, decreased employee turnover, and increased employee retention.

-Assumed to be valued proportionally to the telecommuter's annual salary, as done by JALA Associates (1990).

- Treated as a Monte Carlo variable in simulations and allowed to vary between 0 and 15\%, assuming a uniform distribution. For additional discussion on productivity, see Westfall (1997).

- Needed to compute value of increased productivity.

- Data are not available to differentiate the average salaries of telecommuters from those of traditional commuters.

- Census figures and 1995 NPTS data indicate that the average individual income is closer to $\$ 25,000 /$ year.

- Assumed that the average telecommuter salary was higher than that of the average traditional commuter.

- Treated as a Monte Carlo variable in simulations and allowed to vary, assuming a normal distribution with a mean of $\$ 35,000$ and a standard deviation of $\$ 6,000$.

- Assumed to be an employer cost, because employers are often required to provide parking for their employees according to Shoup (1997) and the Municipality of Metropolitan Seattle (1993). Empirical research by Shoup and Breinholt (1997) indicates that at least nine out of ten American automobile commuters do not pay for parking at work. Data from the 1995 NPTS S confirms that over 93\% of all automobile commuters park for free at work.

- Found to range between $\$ 3.50$ and $\$ 9.50 /$ day according to the Washington Council of Governments (1991), adjusted for inflation.

- Treated as a Monte Carlo variable and is allowed to vary in simulations according to a uniform distribution between $\$ 3.50$ and $\$ 9.50$.

- One of the most challenging factors to quantify because of high variability in values.

- Assumed a $10 \mathrm{ft}$ by $10 \mathrm{ft}$ office.

- Needed to compute the value of office space benefits.

- Represents the fraction of time that space vacated by a telecommuter is utilized for other purposes.

-Marginal space savings from telecommuting on a part-time basis may not result in direct cost savings; there must be a market for that marginal space. For these reasons, there is scarce research addressing the marginal benefits of office space savings, and this remains a gap in telecommuting benefit-cost literature.

- Values can vary from around $\$ 5 / \mathrm{ft}^{2} /$ month $\left(\$ 60 / \mathrm{ft}^{2} /\right.$ year) in suburban areas to as much as $\$ 65 / \mathrm{ft}^{2} /$ month. ( $\$ 780 / \mathrm{ft}^{2} /$ year) in downtown urban areas according to the Society of Industrial and Office Realtors (1998).

- Because of the high variability of real estate rents in different locations and settings and their utilization due to telecommuting, the value of office space is allowed to vary in the simulations between $\$ 0$ and $\$ 780 / \mathrm{ft}^{2} /$ year. simulation analysis, the monetizing values were allowed to vary and the ranges were used to establish the minimum and maximum allowable values [i.e., between $\$ 0$ and $\$ 8,945 / \mathrm{t}$ for reactive organic gases (ROG), between $\$ 0$ and $\$ 4 / \mathrm{t}$ for carbon monoxide $(\mathrm{CO})$, between $\$ 272$ and $\$ 18,746 /$ t for oxides of nitrogen $\left(\mathrm{NO}_{\mathrm{x}}\right)$, and between $\$ 713$ and $\$ 7,378 / \mathrm{t}$ for particulate matter $(\mathrm{PM})]$.

\section{Results}

In this section, two sets of results are presented. In the first set of results (the "fixed case"), all input values were held constant at the values shown in Tables 4-8, and no growth in telecommuting was assumed. This case allows for the least variability in the results. In the second set of results (the "simulation case"): (1) the 
Table 8. Public Sector Emission Quantifying Inputs and Assumptions

\begin{tabular}{|c|c|c|}
\hline Emission factors & Value & Source \\
\hline $\begin{array}{l}\text { Running emissions-ROG } \\
\text { (gm/veh mile) }\end{array}$ & 0.20 & CARB (1996) \\
\hline $\begin{array}{l}\text { Running emissions-CO } \\
\text { (gm/veh mile) }\end{array}$ & 3.30 & CARB (1996) \\
\hline $\begin{array}{l}\text { Running emissions- } \mathrm{NO}_{\mathrm{x}} \\
\text { (gm/veh mile) }\end{array}$ & 0.57 & CARB (1996) \\
\hline $\begin{array}{l}\text { Running emissions-PM } \\
\text { (gm/veh mile) }\end{array}$ & 0.00 & CARB (1996) \\
\hline $\begin{array}{l}\text { Running emissions }-\mathrm{CO}_{2} \\
\text { (gm/veh mile) }\end{array}$ & 257.59 & CARB (1996) \\
\hline $\begin{array}{l}\text { Running emissions }-\mathrm{SO}_{\mathrm{x}} \\
\text { (gm/veh mile) }\end{array}$ & 0.00 & CARB (1996) \\
\hline $\begin{array}{l}\text { Avoided cold starts } \\
\text { (number/event) }\end{array}$ & 1.0 & $\begin{array}{c}\text { Based on } \\
\text { Mokhtarian (1998) }\end{array}$ \\
\hline $\begin{array}{l}\text { Start emissions-ROG } \\
\text { (gm/veh trip) }\end{array}$ & 2.18 & CARB (1996) \\
\hline $\begin{array}{l}\text { Start emissions-CO } \\
\text { (gm/veh trip) }\end{array}$ & 27.69 & CARB (1996) \\
\hline $\begin{array}{l}\text { Start emissions- }-\mathrm{NO}_{\mathrm{x}} \\
\text { (gm/veh trip) }\end{array}$ & 1.69 & CARB (1996) \\
\hline $\begin{array}{l}\text { Start emissions- }-\mathrm{CO}_{2} \\
\text { (gm/veh trip) }\end{array}$ & 94.49 & CARB (1996) \\
\hline $\begin{array}{l}\text { Emission value-ROG } \\
\text { (dollars/t) }\end{array}$ & $\$ 0.00$ & Wang and Santini (1995) \\
\hline $\begin{array}{l}\text { Emission value-CO } \\
(\text { dollars/t) }\end{array}$ & $\$ 0.00$ & Wang and Santini (1995) \\
\hline $\begin{array}{l}\text { Emission value- }-\mathrm{NO}_{\mathrm{x}} \\
(\text { dollars/t) }\end{array}$ & $\$ 272.00$ & Wang and Santini (1995) \\
\hline $\begin{array}{l}\text { Emission value-PM } \\
\text { (dollars/t) }\end{array}$ & $\$ 713.00$ & Wang and Santini (1995) \\
\hline $\begin{array}{l}\text { Emission value }-\mathrm{CO}_{2} \\
\text { (dollars/t) }\end{array}$ & $\$ 0.00$ & No information available \\
\hline
\end{tabular}

number of telecommuters was allowed to have an S-shaped growth function over the 10-year time period from 1996 to 2005; (2) some variables (Monte Carlo variables) were allowed to take on randomly generated values based on assumed normal or uniform distributions; and (3) some uncertain benefits were allowed in a fraction of the simulation cases. Monte Carlo simulation is a common but powerful technique that allows combinations of variables to fluctuate simultaneously over a given range of values, and the result of the Monte Carlo simulation is a distribution of results from which we can estimate an overall expected value.

\section{Fixed Case}

We briefly summarize the fixed case results; figures illustrating the results are provided in Shafizadeh et al. (2000b). The results reveal that, on average, telecommuter benefits are high with a benefit-cost $(B / C)$ ratio equal to 2.24 , indicating that benefits are more than twice costs. If we divide the total benefits minus the costs by the total number of telecommuters, the average net benefit is more than $\$ 122 /$ telecommuter/year. The largest benefit stems from miscellaneous items (reduced lunch expenses, dry cleaning expenses, etc.) at $40 \%$, followed by the monetized value of travel time savings at $29 \%$, avoided fuel savings at $16 \%$, and avoided insurance and maintenance savings at $15 \%$. Total benefits equal about $\$ 220$ /year, while the primary cost stems from additional energy costs which are estimated to be about $\$ 98 /$ year.

For the employer, on the other hand, the fixed case results yield an employer $B / C$ ratio of 0.52 -well below the break-even value of one-indicating that costs exceed benefits. In this case, the employer losses are more than three times greater than telecommuter benefits. The results indicate that it would cost an employer (on net) almost $\$ 420 /$ telecommuter/year to support a telecommuting program. Furthermore, we can immediately conclude that an employer must achieve an increase in productivity greater than the fixed case value assumed (7.5\%) to yield a net benefit, because productivity is the only employer benefit assumed under the fixed case scenario. Results indicate that equipment hardware/software costs (37\%) and telecommunications costs $(33 \%)$ make up the majority of costs.

The public sector accrues no benefits and experiences a net loss of $\$ 1.3$ billion in fuel tax revenue over the course of 1 year for all telecommuters. Together, these results indicate that fixed case conditions do not encourage home-based telecommuting except for the telecommuter.

\section{Simulation Results}

In the simulation case, 10,000 trials were generated, in which 12 Monte Carlo variables were independently assigned unique random values for each trial, based on the distributions given in the tables and text of the second section of this paper. In addition, three indicator variables independently took on the value zero or one for each trial with the following probabilities: (1) $25 \%$ probability that parking or office space benefits would be realized by the employer in any trial; (2) $20 \%$ probability that air quality benefits would be realized by the public sector in any trial (where the value of those benefits, if realized, was also randomly varied per the discussion in the previous section); and (3) $40 \%$ probability that telecommuters would bear the equipment cost burden rather than their employers. We performed the benefit-cost calculation for each trial, and then graphed histograms of the frequencies of $B / C$ ratios for the telecommuter, the employer, and the public sector, across the 10,000 trials.

These three indicator variables were added to the benefit-cost analysis because they represent critical telecommuting issues as yet unresolved in the telecommuting literature. For example, practice varies on whether the equipment cost burden is borne by the employer or the employee, so we assigned a probability that the cost burden will belong to the employee for a randomly selected case. In the simulation analysis, each indicator is allowed to vary independently, creating eight $\left(2^{3}\right)$ possible combinations of the indicators-although in reality these scenarios may not actually be independent. In many situations, such as those outside of major metropolitan areas, the marginal space savings may be negligible, as may be the case for air quality benefits. For the fixed case, we had conservatively assumed that both space benefits as well as air quality and construction benefits could be neglected. Additionally, it was assumed that the employer would bear the equipment cost burden.

Figs. 3-5 present the simulation case results for the telecommuter, the employer, and the public sector, respectively.

\section{Telecommuter}

In Fig. 3, we clearly see a bimodal distribution. Review of the simulation output and corresponding inputs reveals that the population of telecommuters to the left of the break-even point $(B / C=1)$ is entirely composed of the cases where employees 


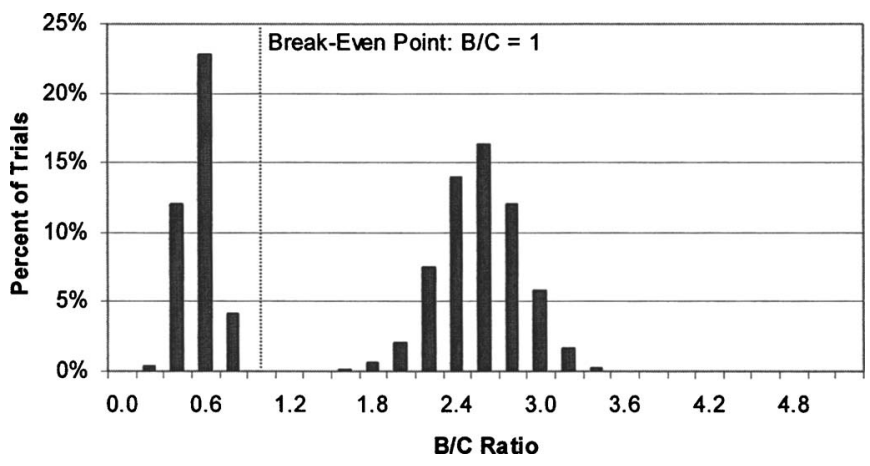

Fig. 3. Telecommuter benefit-cost $(B / C)$ ratio histogram (simulation case)

were required to bear the equipment cost burden. The highest $B / C$ ratio observed for that group is 0.86 , where it is still conceivable that a telecommuter may be willing to telecommute despite a $B / C$ ratio less than one because of intangible benefits that are not quantified (e.g., worker autonomy, personal productivity, family time, etc.). Furthermore, it is altogether possible that unquantifiable benefits such as these play a much larger role in the decision to telecommute than can be accounted for in this type of analysis.

All other trials (where the employer bears the equipment cost burden) yield positive $B / C$ ratios for the employee, ranging between 1.55 and 3.46. From Fig. 3, we can see that the expected $B / C$ ratio for the population on the left is approximately 0.6 (indicating that costs are roughly twice those of benefits, on average), whereas the expected $B / C$ ratio for the population on the right is approximately 2.5 (indicating that benefits are more than twice those of costs, on average). Moreover, because it is assumed that equipment costs paid by the telecommuter are nontransferable in the cases of telecommuter attrition, we find that the total equipment costs are much higher overall when borne by individual telecommuters.

A review of the outputs indicates that negative results are compounded in situations where the commute distance is relatively short (thereby affecting benefits from fuel savings, insurance and maintenance savings, and travel time savings). Some additional benefits can be obtained in the simulation process by the introduction of high individual travel time values. The highest observed $B / C$ ratios for telecommuters exist when the employer bears the cost burden for equipment and software expenses, and the telecommuter benefits from both a high value of individual

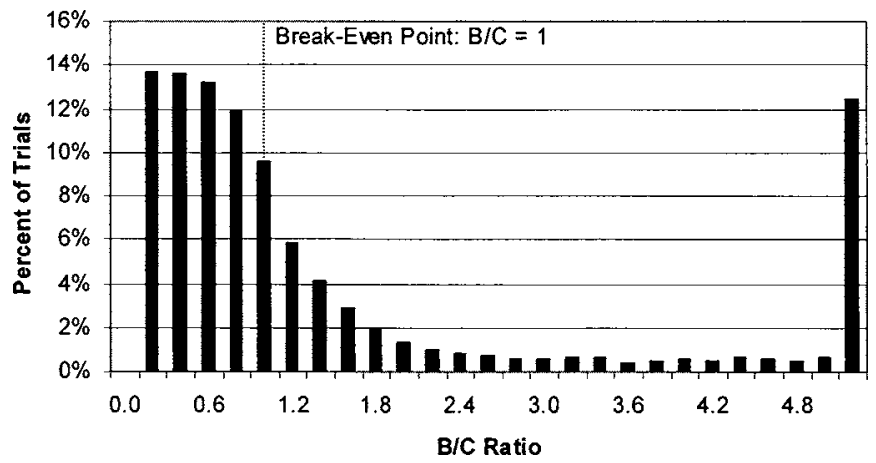

Fig. 4. Employer benefit-cost $(B / C)$ ratio histogram (simulation case)

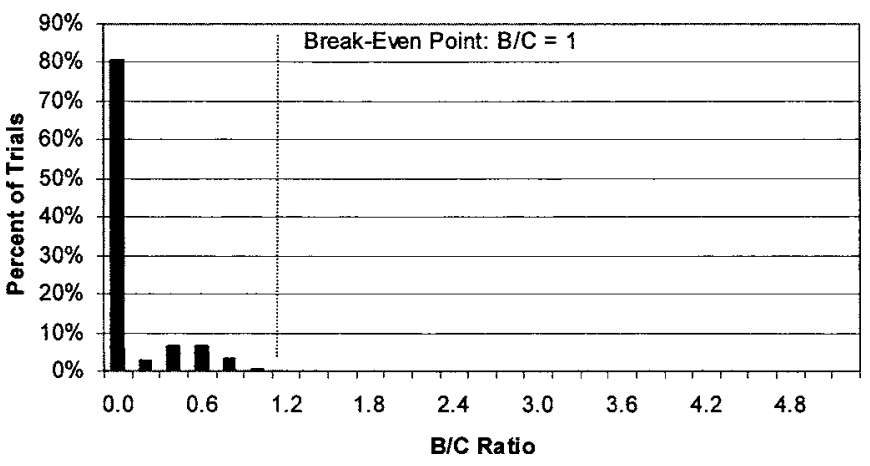

Fig. 5. Public sector benefit-cost $(B / C)$ ratio histogram (simulation case)

travel time and travel cost savings from a longer-than-average commute. Further review reveals that additional home energy costs are more than offset by the miscellaneous benefits that can be achieved from being at home (such as lower food and dry cleaning expenses). From the simulation analysis, we can easily conclude that the single biggest factor affecting the employee's decision to telecommute is that of equipment costs. If asked to pay for equipment and software costs, it is almost certain that a telecommuter will experience a $B / C$ ratio less than one. Even when the commute distance is exceptionally long and/or the telecommuting frequency is very high, the simulation case indicates that telecommuters buying their own equipment will probably not achieve a $B / C$ ratio greater than one. On the other hand, it is quite conservative to attribute the full cost of the equipment to telecommuting, since a PC purchased by the telecommuter will normally be used for personal purposes, and may even have been purchased independently of telecommuting. Thus, the results shown here can be considered worst case.

Because a bimodal distribution has developed, the observed mean from the simulation case histogram is not "typical" for very many people, although it is still a valid representation of the population average under these assumptions. The overall expected $B / C$ ratio for the telecommuter is calculated to be 1.66 , which is above the break-even point but clearly much lower than the value of 2.24 obtained using our fixed case assumptions. This expected value is obtained by averaging the benefit-to-cost ratios across trials, and in general, we see that the cost burden weighs heavily on the overall benefit-to-cost ratio. Furthermore, this comparison indicates that the simulation introduces additional cost uncertainties not considered in the fixed case scenario.

Finally, the simulation results are quite informative as different assumptions produce opposite outcomes and suggest that, as we may have expected, the decision to telecommute may not be simple or straightforward. We find that the difference between benefits and costs for the telecommuter is both: (1) more likely to be negative than positive and (2) more likely to be greater in magnitude when negative than when positive. Specifically, for the approximately 6,000 cases when the difference between telecommuter benefits and costs is negative, its mean value is around - $\$ 280$. For the approximately 4,000 cases when the difference is positive, its mean value is around $\$ 141$. This finding indicates that having benefits greater than costs is less likely and that the reward for telecommuting may not be worth the risk.

\section{Employer}

The simulation case histogram for the employer is shown in Fig. 4, and we begin to see how the inclusion of certain benefits 
can impact the employer's perspective. This histogram highlights the uncertainty in the employer perspective indicated by both very low and very high $B / C$ ratios. Based on these results, we calculate an overall expected $B / C$ ratio to be 1.87 -indicating that the large $B / C$ ratios heavily skew the mean above the break-even point. Clearly, this value represents a major improvement over the ratio of 0.52 obtained with our fixed case results. This comparison indicates that while the employer faces some uncertainty in determining whether to support telecommuting, the potential benefits can be large.

A review of our calculations indicates that these benefits, however, remain contingent on the assumptions of increased employee productivity and office space cost savings. The long "tail" on the right side of the histogram comprises almost exclusively the $25 \%$ of trials in which office and parking space benefits are included. While this verifies the importance of office and parking, inspection of the results indicates that the high office space valuations were amplified by high telecommuting frequencies that led to $B / C$ ratios where the benefits were more than five times greater than the costs. As alluded to in Table 7, it is logical that high frequencies are required to make office space savings a reality, and it also stands to reason that such benefits, if realized, would be large. However, it is also possible that our assumptions regarding space benefits were too generous. For example, it may be that the office space "efficiency factor" should be lowered, or that the office space rent values were allowed to be too high.

If we look only at the cases in which office and parking space savings were neglected, the employer's outcome of course relies almost exclusively on the assumption of increased productivity. Simply put, without productivity (or significant space) benefits, the employer has no easily recognized economic motivation for participating in a telecommuting project. This observation stresses the importance of research in this area-especially when the employer is expected to pay for the majority of expenses.

Additionally, however, we do find that net employer benefits are possible when the equipment costs are shifted to the telecommuter. When the employer's costs are minimized, the telecommuter does not need to increase productivity very much to yield positive results for an employer.

\section{Public Sector}

From Fig. 5, we see how rarely the public sector is expected to realize net economic benefits from telecommuting. Instead, we find that the monetary valuation of air quality benefits do not exceed losses in fuel tax revenue, and the public sector fails to break even. While these and other public sector benefits are still believed to exist (along with net reduction in peak hour commute travel demand in urban areas), it does not appear likely that the public sector can achieve substantial direct benefits.

A review of the modeling process reveals that it would be unrealistic to expect air quality benefits under the following conditions: (1) telecommuting is not concentrated within a localized air basin (represented in the simulation model by the Monte Carlo "dummy" indicator variable, where air quality benefits are assumed to have no market value $80 \%$ of the time); (2) low emissions estimates (due in part to the fact that we are only accounting for running emissions-which represent only a fraction of the total emissions produced); or (3) low emission valuations. More than anything, this study reinforces what has already been known for some time now-that it is difficult for demand-side strategies to compete in the marketplace when their benefits are both difficult to quantify and are not explicitly valued in the open market.

\section{Summary of Results}

Our findings indicate that different results are possible depending on the assumptions made and the uncertainty that is permitted in the model. In the fixed case, the telecommuter is the primary beneficiary $(B / C$ ratio $=2.24)$, while the employer bears the majority of the cost burden $(B / C$ ratio $=0.52)$. In the simulation case the employer $(B / C$ ratio $=1.87)$ is often the recipient of more of the benefits than the telecommuter $(B / C$ ratio $=1.68)$. While it is probable that both telecommuter and employer can develop an arrangement where both parties yield positive economic outcomes, it also remains conceivable that both parties could have bad experiences in a poorly planned telecommuting project. The ideal telecommuting program would resemble an economic "equilibrium" by making tradeoffs between employer and employee so as to maximize total benefits while minimizing total costs.

The results also seem to support the claim that it is possible for the net overall impact of telecommuting to be positive. The average overall $B / C$ ratio (sum of benefits across the three sectors, divided by the sum of costs) from the simulation case analysis (1.53) is much better than the fixed case value (0.69), because the simulation case procedure allows for greater benefits to be included in the model, even if only probabilistically. However, the expected $B / C$ ratio of 1.53 is weighted by the heavy tail of the distribution (representing cases in which private sector office space and parking benefits are realized). In fact, the overall $B / C$ ratio is below the break-even point for more than $60 \%$ of the trials.

\section{Sensitivity Analysis and Discussion}

\section{Adjusting Single Input Values in Fixed Case}

In this section, we present the results obtained after adjusting key input variables one by one (Table 9). The first column represents the input variables that were increased by exactly $10 \%$ from their fixed case input values. The remaining columns show the corresponding percent change in the $B / C$ results. Please note that not all units are identical.

It turns out that the telecommuter is most sensitive to increases in home energy costs-where a $10 \%$ increase from $\$ 2.40$ to $\$ 2.64 /$ telecommute event results in more than a $9 \%$ decrease in the telecommuter $B / C$ ratio. The telecommuter is also sensitive to changes in commute distance and miscellaneous cost savings. A $10 \%$ increase in the one-way commute distance of $11.6 \mathrm{mi}$ results in more than a $3 \%$ increase in the telecommuter $B / C$ ratio, clearly indicating that the telecommuter obtains higher (albeit diminishing marginal) benefits for avoiding longer commutes. The employer is most sensitive to increases in employee salary, telecommuting frequency, and productivity, with increases in the $B / C$ ratio directly proportional to the increases in these variables. The impacts of increases in equipment and communication costs are less than proportional, but non-negligible. Like those for the employer, the overall results are most sensitive to changes in employee salary, telecommuting frequency, and productivity. This indicates the power of these variables in the analysis, since they do not influence the telecommuter and public sector results at all and hence their entire effect on the overall results occurs through the employer perspective.

\section{“Break-Even” Sensitivity Analyses}

We also tried to identify certain threshold levels at which a telecommuting program "breaks even." In other words, these are the 
Table 9. Sensitivity Analysis-Single Input $10 \%$ Increase

\begin{tabular}{|c|c|c|c|}
\hline $\begin{array}{l}\text { Input variable } \\
\text { (10\% increase) }\end{array}$ & $\begin{array}{c}\text { Telecommuter } B / C \\
\text { (percent change) } \\
(\%)\end{array}$ & $\begin{array}{c}\text { Employer } B / C \\
\text { (percent change) } \\
(\%)\end{array}$ & $\begin{array}{c}\text { Overall } B / C \\
\text { (percent change) } \\
(\%)\end{array}$ \\
\hline Commute distance (mi) & 3.4 & 0.0 & 1.0 \\
\hline Employee salary (dollars/year) & 0.0 & 10.0 & 6.7 \\
\hline Telecommuting frequency (days/week) & 0.0 & 10.0 & 8.8 \\
\hline Productivity (\%) & 0.0 & 10.0 & 6.7 \\
\hline Fuel costs (dollars/gal) & 1.6 & 0.0 & 0.5 \\
\hline Fuel economy (mi/gal) & -1.4 & 0.0 & -0.4 \\
\hline Equipment costs (dollars/year) & 0.0 & -3.6 & -3.2 \\
\hline Auto insurance and maintenance (dollars/mi) & 1.5 & 0.0 & 0.5 \\
\hline Miscellaneous cost savings (dollars/event) & 4.0 & 0.0 & 1.3 \\
\hline Additional energy costs (dollars/event) & -9.1 & 0.0 & -1.0 \\
\hline Equipment service/maintenance cost (dollars/year) & 0.0 & -2.0 & -1.8 \\
\hline Communications startup cost (dollars) & 0.0 & -0.3 & -0.3 \\
\hline Communications service cost (dollars/year) & 0.0 & -2.9 & -2.6 \\
\hline Training costs (dollars/telecommuter-supervisor pair) & 0.0 & -0.9 & -0.8 \\
\hline Fuel tax (dollars/gal) & 0.0 & 0.0 & -0.1 \\
\hline
\end{tabular}

Note: Because the fixed case $B / C$ ratio for the public sector was calculated to be zero, any change cannot be defined. Therefore, the public sector perspective is omitted from this table; however, public sector results are included in the overall change presented in the final column.

minimum telecommuting levels that must be met for the telecommuter or the employer to obtain positive economic outcomes from telecommuting, assuming all else remains constant (as given by the fixed case assumptions). Knowing these threshold values can simplify decision making. In particular, we examine the following:

1. The minimum level of productivity that the employer would need for benefits to equal equipment costs (for employees with different annual salaries and at different equipment costs); and

2. The minimum parking space value that the employer would need for benefits to offset the necessary equipment burdenwith and without assuming an increase in productivity by telecommuters.

\section{Minimum Productivity Levels Necessary for Employer to "Break Even"}

Because increased productivity can be one of the primary economic motivations for supporting a telecommuting program, we decided to explore its relationship to the telecommuter's income. Looking at different employee salaries and equipment costs (assuming the employer pays), we determine the required level of productivity that telecommuting must achieve for the employer to break even. Because the value of productivity is a function of employee salary, we would expect the required levels of productivity to decrease as employee salaries increase, in order to reach the same benefit value.

Using our fixed case assumptions, we found that the employer only needs to achieve an increase in productivity of about $15 \%$ or higher on telecommuting days to break even given our base-case assumptions of $\$ 1,800$ equipment costs and $\$ 35,000$ annual salary. Moreover, when we are reminded that for the purposes of this study "increased productivity" is defined as increased quality or quantity of work, increased time spent working, decreased sick leave, decreased employee turnover, and increased employee retention, it is not difficult to suggest that a $15 \%$ increase in productivity is attainable.

Because productivity is a function of the employee's compensated value, we also looked at the effect of the telecommuter's salary on the required level of productivity required for the employer to break even. In other words, sensitivity analysis was performed to explore how higher salaried employees have lower minimum productivity requirements for the employer to "break even." In Fig. 6, we can see how the productivity required to break even (with equipment costs ranging from $\$ 1,000$ to $\$ 3,000$ per telecommuter over the life of the equipment, approximately 5 years) drops as income levels increase. From Fig. 6, we see (not surprisingly) that employers can maximize their economic benefit by encouraging their most "valuable" employees to be the most productive through telecommuting.

\section{Minimum Parking Space Values Necessary for Employer to "Break Even"}

Because office space benefits remain uncertain, we test breakeven points with parking space benefits and without office space benefits. We find that if the employer saves more than approximately $\$ 13.40 /$ telecommuter/day, on average, then the employer will break even without any office space benefits. While we are still assuming a $7.5 \%$ increase in productivity by each telecommuter, the fixed case also assumes that the employer will pay for the equipment. In other words, the employer could afford to supply all of its telecommuting employees with equipment if it were not required to provide parking at a cost of $\$ 13.40$ (or more)/ employee/day. If we neglect productivity altogether and assume that all employer benefits come from parking, the minimum parking space value skyrockets to $\$ 28.00 /$ telecommuter/day, indicating that some productivity increase should still be expected for the employer to achieve net benefits.

\section{Conclusions}

While many costs and benefits remain uncertain, in this study we were able to identify some situations in which telecommuting was most (and least) attractive to the telecommuter and the employer. It is not surprising that conditions for the employee (the telecommuter) are generally most favorable when: (1) the employer bears 


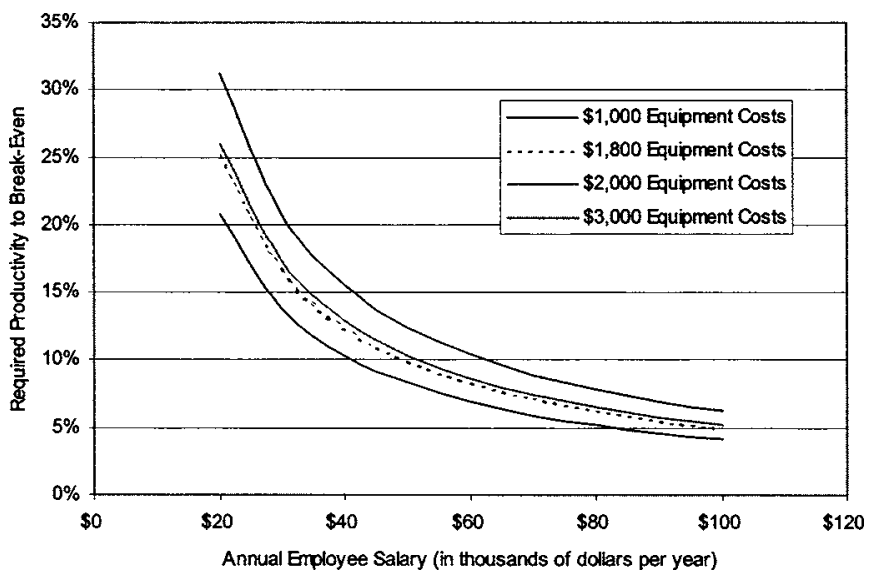

Fig. 6. Productivity required by employers to "break even" given equipment costs and employee salaries

the equipment cost; (2) commute distances are above average; (3) the commute vehicle has below-average fuel economy; (4) travel time is highly valued; and (5) telecommuting is frequent. What was not obvious at the outset is that benefits are unlikely to exceed costs if the telecommuter is asked to bear the full equipment cost burden. Conditions are most favorable for the employer when: (1) the telecommuter bears the equipment cost; (2) there is low telecommuter attrition; (3) the employee is highly productive on telecommuting days; (4) the employee's time is highly valued; and (5) telecommuting is frequent. For the employer, telecommuting is also favorable if parking and office space savings are realized.

With conservative assumptions about current conditions in our fixed case, we find that telecommuting yields average $B / C$ ratios less than one from all perspectives except that of the telecommuter, indicating that telecommuting may often not be an economically justifiable alternative to traditional commuting behavior. This conclusion is consistent with observed practice, which finds that telecommuting is growing more slowly than many observers expected, and may not be adopted in many cases where it is technically feasible and apparently advantageous for the employee.

The simulation case, however, allowed for the introduction of more uncertainty with respect to costs and benefits and thus closer-to-real-world representation. These results indicated that the telecommuter's overall $B / C$ ratio could be lower than the fixed case suggested, while the employer's and public sector's overall $B / C$ ratios could be higher. The introduction of parking and office space benefits allows favorable $B / C$ ratios for employers to be more easily obtained.

For the public sector, it is difficult to justify localized benefits but we maintain that there is an overall rationale for promoting telecommuting as a way of mitigating traffic on the entire transportation network. While public sector assistance at the local or regional level could yield some public benefits, such as reduced congestion or improved travel speed, these benefits remain difficult to quantify and monetize, because they are relatively small and dispersed throughout the transportation system. When the benefits are dispersed over a wide area, it is more likely that the dominating factor in the public sector $B / C$ calculation will be the lost fuel tax revenues due to telecommuting. In this situation, the success of telecommuting would rely entirely on both the employer and the employee impetus to achieve adequate perceived benefits. In general, if the public sector does receive some noticeable net benefit from telecommuting in the form of avoided infrastructural construction costs or air pollution impacts, its role would be to support either the employer or the employee to encourage telecommuting.

Additional sensitivity analyses indicate that, with other factors at their fixed case values, productivity benefits need to exceed $15 \%$ on telecommuting days for telecommuters with annual salaries of approximately $\$ 35,000$, in order for the employer to break even. As the employee salary increases, the amount of productivity needed to "break even" decreases. Additionally, employers can obtain net positive results if they save $\$ 13.40$ or more/ telecommute event, e.g., on parking costs.

One of the general observations from this research is simply the fact that even when we combine all of the empirical evidence surrounding the costs and benefits of telecommuting, we find that it may not make "economic sense" to telecommute. Depending on the underlying assumptions, it is possible for all participants to experience negative economic impacts from telecommuting. While telecommuting continues to grow and continues to be touted by transportation planners, a great deal of uncertainty remains present in this model. It remains likely that costs are overstated and benefits are understated in this model and that unquantifiable benefits play a much larger role in the decision to telecommute than can be expressed in a benefit-cost analysis.

One limitation to this study is that numerous assumptions had to be made. Ideally, we would want to compare the results obtained here with results from empirical benefit-cost evaluations. One of the inherent assumptions in this paper is that transportation-related benefits to the telecommuter stem from forgone single-occupant automobile travel and are a function of auto commute distance (i.e., avoided fuel costs, travel time savings, avoided insurance and maintenance costs). This paper does not attempt to look at the economic evaluations of other modes. As a result, we see that commuters with long commutes in singleoccupancy vehicles with poor fuel economy would experience the largest benefits. If alternative modes, such as transit, were to be included in this analysis, we would not observe a reduction in fuel consumption. A telecommuter shifting from a transit mode would probably not yield as many benefits through avoided fuel costs but would likely yield greater benefits in terms of travel time saved. As with other forms of transportation infrastructure, forgone transit trips would yield no benefit to the public sector unless it is large enough to bring about a reduction in services supplied (e.g., decreased service frequency). Otherwise, the public sector case would only be worsened by the decrease in farebox revenue.

Another limitation of this model is the limited number of distributions that were used to perform the simulation. Aside from normal and uniform distributions, we did not explore many other options, and as a result some variables were artificially bounded by low variances to avoid obtaining unrealistic values, such as negative distances. This makes it difficult to model some situations that may be of interest, such as exceptionally long commutes and commutes with high levels of variability. For count variables (such as average telecommuting frequency), it would be appropriate in future studies to experiment with distributions such as the Poisson or negative binomial, which would avoid the generation of negative values. For continuous variables (such as commute length), distributions such as the log-normal, chi-squared, and other members of the gamma family can be investigated.

Future research should be aimed at revising inputs and reducing the need for assumptions and theoretical scenarios, focusing 
on the decision variables especially important to telecommuters and their managers. We need additional understanding of telecommuting frequency and attrition over time for improved benefit-cost analysis, and better understanding of productivity changes as a result of telecommuting.

\section{Acknowledgments}

This project was partially funded by Partners for Advanced Transit and Highways (PATH) of the University of California, in cooperation with the State of California Business, Transportation, and Housing Agency, Department of Transportation; and the United States Department of Transportation, Federal Highway Administration. The contents reflect the views of the writers who are responsible for the facts and accuracy of the data presented herein. The contents do not necessarily reflect the official views or policies of the State of California.

\section{References}

American Automobile Association (AAA). (1998). Your driving costs, 1998 Ed., Runzheimer International, Park Rochester, Wis.

American Petroleum Institute (API). (1998). "How much we pay for gasoline: 1997 Annual review." Publication No. R26903, Washington, D.C., April.

Bernardino, A., and Ben-Akiva, M. (1996). "Modeling the process of adoption of telecommuting: A comprehensive framework." Transportation Research Record. 1552, Transportation Research Board, Washington, D.C., 161-170.

Bernardino, A. T., Ben-Akiva, M., and Salomon, I. (1993). "Statedpreference approach to modeling the adoption of telecommuting." Transportation Research Record. 1413, Transportation Research Board, Washington, D.C., 22-30.

Blackman, W. A., Jr. (1974). "The market dynamics of technological substitutions.” Technol. Forecast. Soc. Change, 6(1974), 41-63.

California Air Resources Board (ARB). (1996). Methodology for estimating emissions from on-road motor vehicles, Vol. II: EMFAC7G, Sacramento, Calif.

County of San Diego Department of Public Works (CSD-DPW). (1990). Telecommuting Pilot Study Final Rep., San Diego.

Dowling Associates, Inc. (1999). "24-hour travel time savings project." Task No. 2 Draft Rep.: Evaluation of Methodology Prepared for the Washington State Dept. of Transportation, Olympia, Wash.

Duxbury, L. E., Higgins, C. A., and Irving, R. H. (1987). "Attitudes of managers and employees to telecommuting." INFOR, 25(3), 273-285.

Finlay, S. (1991). "Benefits, costs, and policy strategies for telecommuting in greater Vancouver." Master's thesis, Simon Fraser Univ., Vancouver, B.C., Canada.

Frankel, G. (1996). "Can the cost of a home computer be written off?" Tax Adviser, 27(4), 238-242, 〈http://www.aicpa.org/pubs/taxadv/ index.htm $\rangle$.

Gordon, G. (1997). "Telecommuters by the millions-11 million, to be exact." Telecommuting Review: The Gordon Rep., 14(8), 14-16.

Gordon, G. E., and Kelly, M. M. (1986). Telecommuting: How to make it work for you and your company, Prentice-Hall, Englewood Cliffs, N.J.

Gray, M., Hodson, N., and Gordon, G. (1993). Teleworking explained, Wiley, New York.

Handy, S. L., and Mokhtarian, P. L. (1995). "Planning for telecommuting: Measurement and policy issues." J. Am. Plan. Assn., 61(1), 99-111.

Handy, S. L., and Mokhtarian, P. L. (1996). "Forecasting telecommuting." Transportation, 23(1), 163-190.

JALA Associates, Inc. (1990). The State of California Telecommuting
Pilot Project Final Rep., Dept. of General Services, State of California, Sacramento, Calif.

JALA International, Inc. (1993). City of Los Angeles Telecommuting Project Final Rep., Dept. of Telecommunications, City of Los Angeles, Los Angeles.

Katz, A. I. (1987). "The management, control, and evaluation of a telecommuting project: A case study." Inf. Manage., 13(4), 179-190.

Krusi, F. E. (1997). "Departmental guidance for the valuation of travel time in economic analysis." U.S. Dept. of Transportation memorandum from the Assistant Secretary for Transportation Policy, (April 9, 1997), Washington, D.C.

Kugelmass, J. (1995). Telecommuting: A manager's guide to flexible work arrangements, Lexington Books, New York.

Kunkle, R. (1992). "Puget sound telecommuting demonstration case studies." Washington State Energy Office Publication 92-146, Olympia, Wash., November.

Mahmassani, H. S., Yen, J.-R., Herman, R., and Sullivan, M. A. (1993). "Employee attitudes and stated preferences toward telecommuting: An exploratory analysis." Transportation Research Record. 1413, Transportation Research Board, Washington, D.C., 31-41.

Mokhtarian, P. L. (1998). "A synthetic approach to estimating the impacts of telecommuting on travel." Urban Stud., 35(2), 215-241.

Mokhtarian, P. L., Handy, S. L., and Salomon, I. (1995). "Methodological issues in the estimation of travel, energy, and air quality impacts of telecommuting." Transp. Res., Part A: Policy Pract., 29A(4), 283-302.

Mokhtarian, P. L., and Salomon, I. (1996). "Modeling the choice of telecommuting. 3: Identifying the choice set and estimating binary choice models for technology-based alternatives." Envir. Plan. A, 28(10), 1877-1894.

Mokhtarian, P. L., and Salomon, I. (1997). "Modeling the desire to telecommute: The importance of attitudinal factors in behavioral models." Transp. Res., Part A: Policy Pract., 31A(1), 35-50.

Mokhtarian, P. L., Salomon, I., and Choo, S. (2005). "Measuring the measurable: Why can't we agree on the number of telecommuters in the US?" Quality and Quantity, 39, 423-452.

Metropolitan Washington Council of Governments. (1991).“The impacts of parking prices on commuter travel." Washington, D.C., December.

Municipality of Metropolitan Seattle. (1993). "Managing employee parking in a changing market." Service Development Division Pamphlet, Seattle, November.

National Highway Traffic Safety Administration. (1997). "Automotive Fuel Economy Program, Twenty-Second Annual Report to Congress, Calendar Year 1997.” 〈http://www.nhtsa.dot.gov/cars/problems/ studies/fuelecon/>.

Nilles, J. M. (1994). Making telecommuting happen: A guide for telemanagers and telecommuters, Van Nostrand Reinhold, New York.

Reed, T. L., Niemeier, D. A., and Rutherford, G. S. (1995). "Prioritization of capacity improvements." Publication No. WA-RD 295.1, Washington State Dept. of Transportation, Olympia, Wash.

Schrank, D., and Lomax, T. (1999). The 1999 Annual Mobility Rep.Information for Urban America, Texas Transportation Institute, Texas A\&M Univ., College Station, Tex.

Shafizadeh, K., Mokhtarian, P. L., Niemeier, D., and Salomon, I. (2000a). "The costs and benefits of telecommuting: An evaluation of microscale studies and promotional literature." California PATH Research Rep. No. UCB-ITS-PRR-2000-13, Berkeley, Calif.

Shafizadeh, K., Mokhtarian, P. L., Niemeier, D., and Salomon, I. (2000b). "The costs and benefits of telecommuting." California PATH Research Rep. No. UCB-ITS-PRR-2000-20, Berkeley, Calif., November.

Shafizadeh, K., Niemeier, D. A., Mokhtarian, P. L., and Salomon, I. (1998). "The costs and benefits of telecommuting: An evaluation of macro-scale literature." Research Rep. No. UCD-ITS-RR-97-23, Institute of Transportation Studies, Univ. of California, Davis, Calif.

Shoup, D. (1997). "Evaluating the effects of parking cash out: Eight case studies." Rep. Prepared for California Air Resources Board, Sacramento, Calif.

Shoup, D., and Breinholt, M. J. (1997). "Employer-paid parking: A 
nationwide survey of employers' parking subsidy policies." The full social costs and benefits of transportation, D. Greene, D. Jones, and M. Delucchi, eds., Springer, Berlin, 371-385.

Society of Industrial and Office Realtors. (1998). Comparative statistics of industrial and office real estate markets, Washington, D.C.

Southern California Association of Governments (SCAG). (1988). Evaluation Rep.: Telecommuting Pilot Project for the Southern California Association of Governments, Environmental Planning Dept., Southern California Association of Governments, Los Angeles.

U.S. Department of Commerce, Economics and Statistics Administration, Bureau of the Census, Data User Services Division. (1998). Statistical abstract of the United States 1997, Washington, D.C.

U.S. Department of Energy (U.S. DOE). (1994). Energy, emissions, and social consequences of telecommuting, Office of the Secretary, U.S. Government Printing Office, Washington, D.C.

U.S. Department of Transportation (U.S. DOT). (1993). Transportation implications of telecommuting, Office of the Secretary. U.S. Government Printing Office, Washington, D.C.

U.S. Department of Transportation (U.S. DOT). (1997). Successful Telecommuting Programs in the Public and Private Sectors: A Rep. for Congress, U.S. Dept. of Transportation, Washington, D.C.

U.S. Federal Highway Administration (FHwA). (1992). "Cost of owning and operating automobiles, vans, and light trucks, 1991." FHWA
Publication No. FHWA-PL-92-019, Washington, D.C.

U.S. Federal Highway Administration (FHwA). (1997). "1995 NPTS early results report." 〈http://www.cta.ornl.gov/npts/1995/doc/ NPTS_Booklet.pdf $>$.

Varma, K. V., Ho, C.-I., Stanek, D. M., and Mokhtarian, P. L. (1998). "Duration and frequency of telecenter use: Once a telecommuter, always a telecommuter?" Transp. Res., Part C: Emerg. Technol., 6(1-2), 47-68.

Wang, M. Q., and Santini, D. J. (1995). "Monetary values of air pollutant emission in various U.S. regions." Transportation Research Record. 1475, Transportation Research Board, Washington, D.C., 33-41.

Westfall, R. D. (1997). "Remote work: A conceptual perspective on the demand for telecommuting." Doctoral dissertation, Claremont Graduate Univ., Claremont, Calif.

Yen, J.-R. (2002). "The economic evaluation of telecommuting on highway infrastructure: A case study of Taiwan." Economic evaluation of advanced technologies: Techniques and case studies, J. P. Lavelle, H. R. Liggitt, and H. R. Parsaei, eds., Taylor \& Francis, New York, 191-199.

Yen, J.-R., Mahmassani, H. S., and Herman, R. (1994). "Employer attitudes and stated preferences toward telecommuting: An exploratory analysis." Transportation Research Record. 1463, Transportation Research Board, Washington, D.C., 15-25. 